\title{
Synoptic climatological analysis of Red Sea Trough and non-Red Sea Trough rain situations over Israel
}

\author{
Y. Tsvieli and A. Zangvil \\ The Blaustein Institute for Desert Research, Ben Gurion University, Sde Boker Campus, Israel \\ Received: 28 February 2007 - Revised: 24 July 2007 - Accepted: 2 October 2007 - Published: 15 October 2007
}

\begin{abstract}
Winter (October to April) rainfall in Israel is caused mostly by migrating Mediterranean cyclones but certain rain situations are accompanied by a low pressure trough extending northward from the southern Red Sea towards the Eastern Mediterranean (EM) and the Levant. This system, the Red Sea Trough (RST) is one of the most frequent surface atmospheric circulation patterns over the southeastern Mediterranean, but most of the RSTs are not accompanied by rain. This paper presents a synoptic climatological comparative analysis between rain situations associated with RSTs, and those not connected with RSTs (non-RST rain, NRR). The RST situations were identified objectively with the aid of a new algorithm applied to the GEOS-1 reanalysis gridded data set from NASA, for the period of March 1985November 1995.

Results show that RST rain is accompanied by a relatively narrow $500-\mathrm{hPa}$ trough, located west of the Israeli coast-line and characterized by a deep southward penetration, while Non-RST-associated rain (NRR) is accompanied by a wider upper trough, located over the Israeli coast-line with a shallower southward penetration. We found a southsouthwesterly wind vector anomaly at $200 \mathrm{hPa}$ over Israel during RST rains, while during NRRs a similar wind vector anomaly pattern is observed east of Israel. There is a divergence center over, or a few degrees east of Israel during RST rains, while NRR is associated with a divergence value of nearly zero over Israel and a maximum divergence center located east of Israel. The moisture flux during NRR at 700 and $900 \mathrm{hPa}$ is from the Mediterranean, while during RST rain there is a south-westerly moisture flux at $700 \mathrm{hPa}$ from equatorial Africa to Israel and vicinity. A steeper temperature lapse-rate between $950-500 \mathrm{hPa}$ was found during RST rain compared with NRR, resulting from a combination of cooling aloft together with heating near the surface.
\end{abstract}

Correspondence to: A. Zangvil

(zangvil@bgu.ac.il)

\section{Introduction}

The rainy season in Israel lasts from October to April. During this period migrating cyclones associated with cold upper troughs are moving from west to east over the Mediterranean Sea and from time to time they affect Israel. (See reviews in Air Ministry, 1962 and in Goldreich, 2003) Sometimes the upper troughs are not associated with a Mediterranean cyclone but with a Red Sea Trough (RST). The RST is a tongue of low pressure extending northward from the southern Red Sea towards the Eastern Mediterranean (EM) and the Levant, at lower atmospheric levels. The origin of the RST is the "Sudan Monsoon Low", a part of a large-scale subtropical/equatorial low-pressure thermal system. The development, intensity and northward extension of the RST is usually attributed to topographic and thermal forcing factors over the Red Sea region (Itzigsohn, 1995; Krichak et al., 1997a, b).

The RST is most frequently observed during fall and spring (Dayan and Sharon, 1980; Zangvil and Shemer, 1986; Sharon and Kutiel, 1986; Kahana et al., 2002; Ziv, 1994; Goldreich, 2003; Tsvieli and Zangvil, 2005). It may affect the region also in winter, but in the summer (June to September) it disappears altogether.

Generally, the RST is associated with hot and dry weather conditions over Israel and vicinity, resulting from eastsoutheasterly flows at the lower atmosphere. In some, less frequent cases, the RST is accompanied by an upper trough extending from the north over the EM. This upper trough enhances upward motion and unstable conditions, favoring the development of convective storms, occasionally accompanied by heavy showers and thunderstorms, mainly at the eastern and southern parts of Israel (Ziv, 1994; Saaroni et al., 1998; Kahana et al., 2002; Goldreich, 2003).

The majority of rain situations over Israel result from cyclones crossing the Mediterranean from west to east during the rainy season, October-April (non-RST rain situations).

Published by Copernicus Publications on behalf of the European Geosciences Union. 


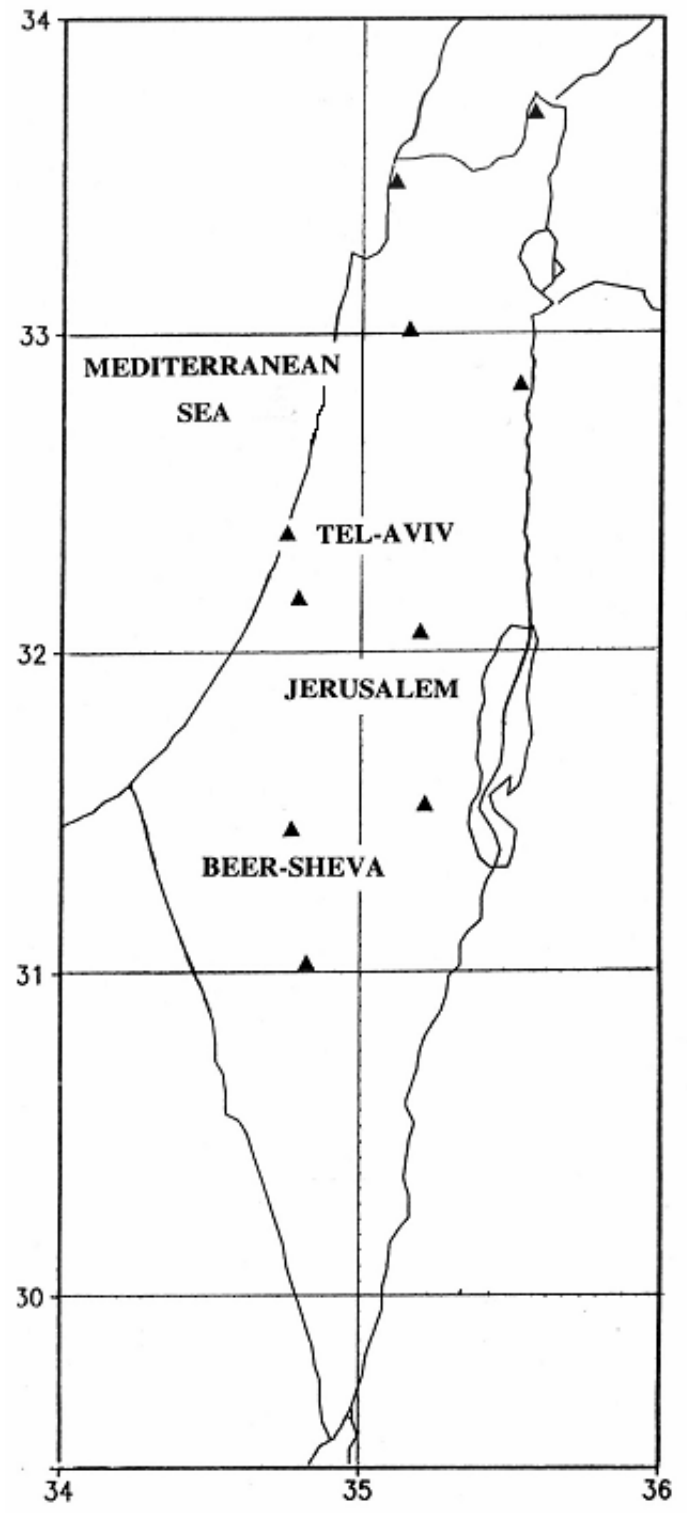

Fig. 1. Rain-measuring stations in the study region (black triangles).

The RST rain is a secondary source of the rain over Israel, especially in the southern and eastern parts of the country (Ziv, 1994; Kidron and Pick, 2000; Goldreich, 2003).

The moisture sources of the rain over Israel have been studied in several works in conjunction with synoptic situations, air mass trajectory analysis or satellite infrared information (e.g., Leguy et al., 1983; Sasson, 1990; Zangvil and Druian, 1990; Sasson and Zangvil, 1994; Alpert and ShayEl, 1994; Yakir et al., 1996 and Zangvil et al., 2003). Moisture flux and moisture flux divergence calculation were carried out by Zangvil and Isakson (1995); Fengjun (2005), and Malka (2006).

The objectives of this paper are to study the differences between the synoptic and humidity field characteristics of rain situations associated with RSTs and those not connected with RSTs (non-RST rain, or NRR).

\section{Data and method}

The RST situations were identified objectively, based on a new, simple algorithm that was developed in our laboratory (Tsvieli and Zangvil, 2005) and applied to the NASA GEOS1 reanalysis 6 hourly gridded data set $\left(2^{\circ}\right.$ Lat. $\times 2.5^{\circ}$ Lon $)$ for the period of March 1985-November 1995. This data set has been specially developed for the Mediterranean region by DaSilva and Alpert (1996). The grid data are displayed on geographical charts by the Grid Analysis and Display System (GrADS) developed by Doty (1988). Daily rainfall data from 10 representative rain-measuring stations were obtained from the Israel Meteorological Service (Fig. 1).

As described in details in Tsvieli and Zangvil (2005), we defined RST rain situations over Israel on the basis of the daily rainfall in Israel, in conjunction with the objectively defined RSTs at each map time. The rest of the map times associated with rain situations were defined as non-RST rain situation (NRR). Composite analysis of several meteorological variables was applied to the two groups of maps for each month from October to May during the period March 1985November 1995. The results are shown in Sect. 3.

\section{Results and discussion}

In this Section we present results of a comparative analysis of the synoptic features of RST rain events and non RST rain events from several points of view. We start with a comparison of sea level and $500 \mathrm{hPa}$ circulation systems. Next we analyze the Jet stream and divergence field at the $200 \mathrm{hPa}$ level, followed by a description of the moisture field and thermal structure for the two types of rain situations.

\subsection{Sea level and $500 \mathrm{hPa}$ circulation patterns}

Examination of the sea level pressure and $500 \mathrm{hPa}$ geopotential height charts showed remarkable differences between RST rain and non-RST rain situations. We next show representative examples of the long-term mean monthly composite charts for these two categories.

Figures 2 and 3 show the main synoptic differences between RST rain and non-RST rain (NRR) situations. Near the surface (Fig. 2a) NRRs are associated with a closed cyclone centered between the island of Cyprus and the Syrian coast-line (known as the Cyprus low) and with a negative sea level pressure anomaly center over northeastern Syria, near $37.5^{\circ} \mathrm{N}, 40^{\circ} \mathrm{E}$ (Fig. 2b). The RST rains are associated with a pronounced sea level pressure trough extending northward over Israel and the eastern Mediterranean (Fig. 3a), and a negative sea level pressure anomaly located near $30^{\circ} \mathrm{N}$, $40^{\circ}$ E (Fig. 3b). 

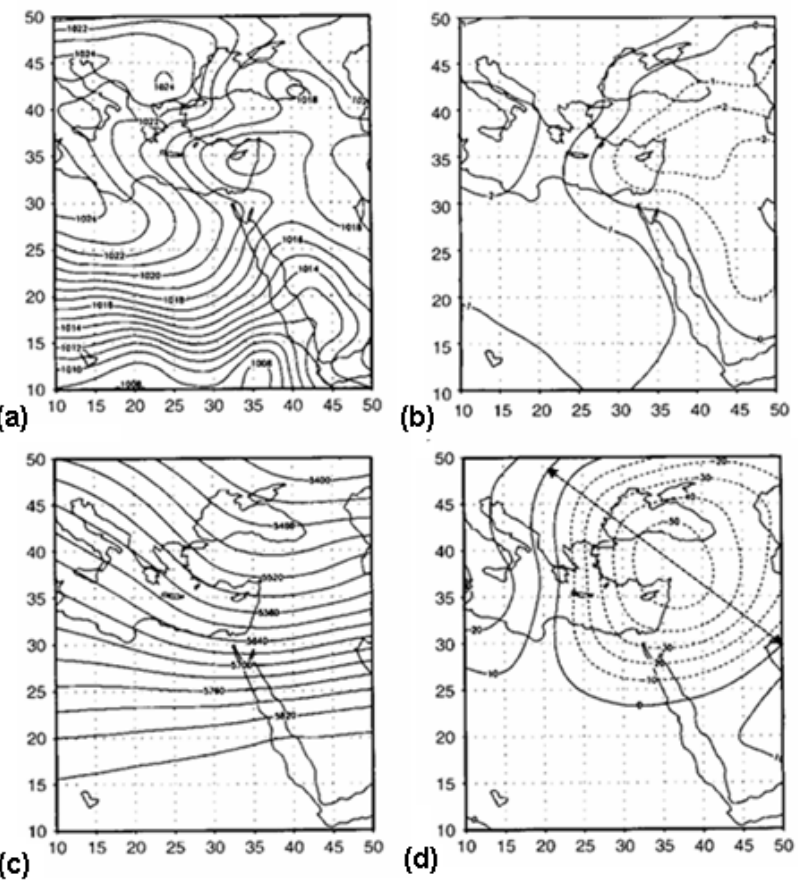

Fig. 2. Composite charts of non-RST rain situations in January (1986-1995): (a) SLP [hPa]; (b) SLP deviation from the (19861995) monthly mean; (c) $500 \mathrm{hPa}$ geopotential height [m]; (d) $500 \mathrm{hPa}$ height deviation from the (1986-1995) monthly mean. Arrow denotes the width of the $500 \mathrm{hPa}$ trough. Number of cases (map times) in composites for non-RST rain: 271.

The NRRs at $500 \mathrm{hPa}$ are accompanied by a relatively wide trough with its meridional axis located over the Israeli coast-line (Fig. 2c). During RSTs rain in January the $500 \mathrm{hPa}$ trough axis is located about 2.5 degrees longitude west of the Israeli coast-line (Fig. 3c), and up to about 57.5 degrees west of the Israeli coast-line during the transition season months (not shown).

The $500 \mathrm{hPa}$ geopotential height anomalies accompanying NRR (Fig. 2d) show the wide extent (about $30^{\circ}$ longitude wide) and the relatively shallow southward penetration (only to about, $25^{\circ} \mathrm{N}$ ) with a negative anomaly center located near $37^{\circ} \mathrm{N}, 37^{\circ} \mathrm{E}$. In contrast, The RST rains are accompanied by relatively narrower troughs (about $20^{\circ}$ longitude wide), with relatively weak geopotential height gradients but a deeper southward penetration (to about, $15^{\circ} \mathrm{N}$ ) and a negative anomaly center located near $32^{\circ} \mathrm{N}, 33^{\circ} \mathrm{E}$ (Fig. 3d). We should bear in mind that the apparent wider upper trough for the non-RST cases may reflect the variety of troughs (in both location and structure), and does not necessarily indicate that the individual troughs belonging to this class are wider.

\subsection{Subtropical Jet Stream and divergence at $200 \mathrm{hPa}$}

At the $200 \mathrm{hPa}$ pressure level we found that during NRRs the Subtropical Jet Stream core is located eastward compared to
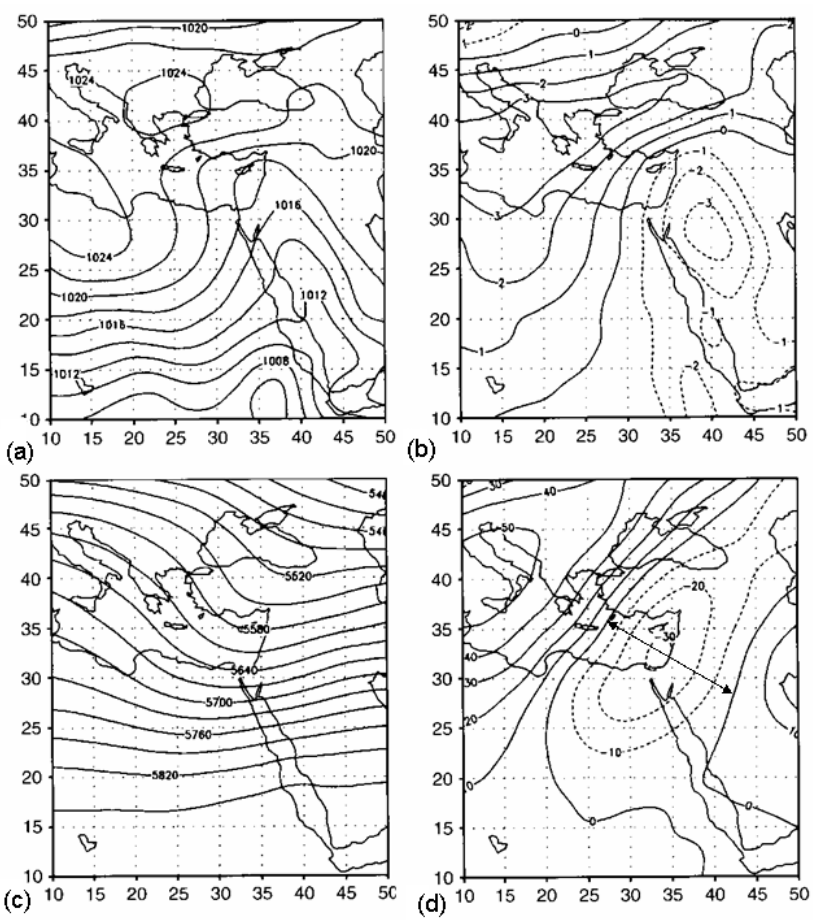

Fig. 3. Composite charts of RST rain situations in January (19861995): (a) SLP [hPa]; (b) SLP deviation from the (1986-1995) monthly mean; (c) $500 \mathrm{hPa}$ geopotential height [m]; (d) $500 \mathrm{hPa}$ height deviation from the (1986-1995) monthly mean. Arrow denotes the width of the $500 \mathrm{hPa}$ trough. Number of cases (map times) in composites for RST rain: 90.

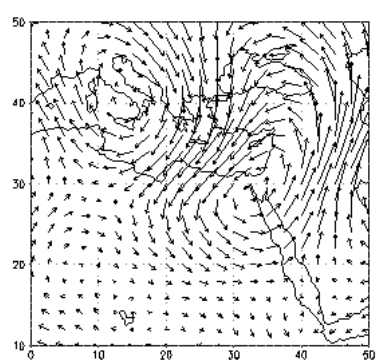

(a)

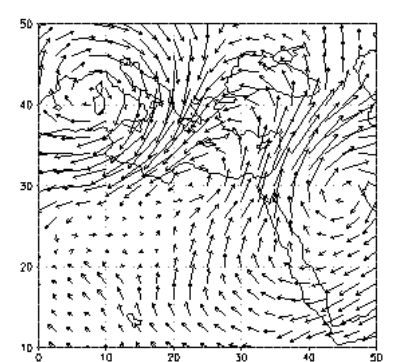

(b)
Fig. 4. Composite charts of $200 \mathrm{hPa}$ wind vector deviation from the (1985-1995) monthly mean, in March: (a) non-RST rain; (b) RST rain. Arrow denotes the value of the vector scale $[\mathrm{m} / \mathrm{s}]$. Number of cases (map times) in composites for non-RST rain: 213, and for RST rain: 104 .

the monthly mean (1985-1995) location, with an increase of the wind speed south or south-east of Israel (not shown). The RST rains during most of the rainy months are associated with a small decrease of wind speed over Israel (not shown). On the other hand, we found a south-southwesterly wind vector anomaly at $200 \mathrm{hPa}$ over Israel during RST rains, especially in the fall and spring months, represented here 


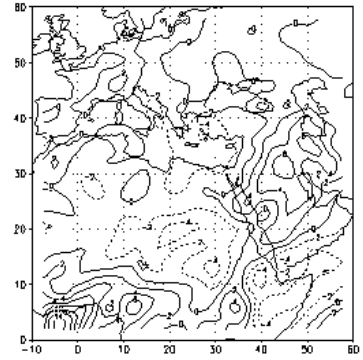

(a)

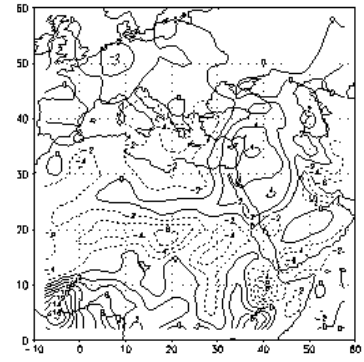

(b)
Fig. 5. Composite charts of $200 \mathrm{hPa}$ divergence $\left[\times 10^{-6} \mathrm{~s}^{-1}\right]$ in March (1985-1995): (a) non-RST rain; (b) RST rain. (a)

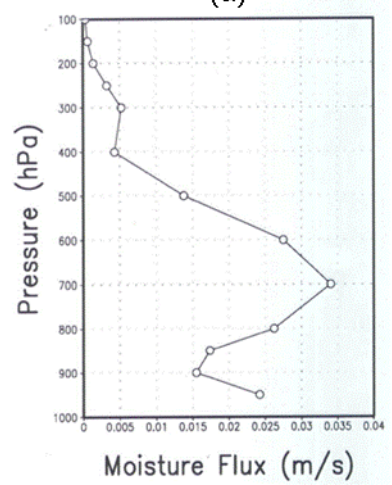

(b)

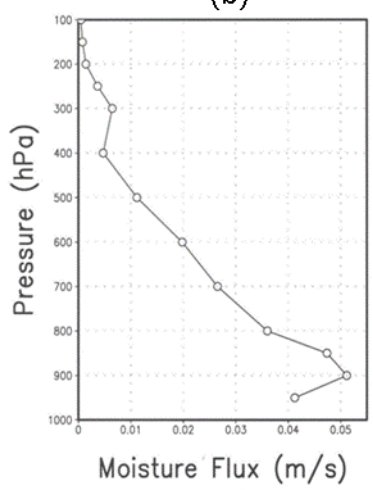

Fig. 6. Composite vertical profiles (1985-1995) of the moisture flux $q \times v,(q$ is the specific humidity and $v$ is the scalar wind speed) at $32^{\circ} \mathrm{N}, 35^{\circ} \mathrm{E}$ in October, for (a) RST rain; (b) non-RST rain. Number of cases (map times) in composites for RST rain: 141, and for non-RST rain: 61.

by the month of March (Fig. 4b) indicating a southwesterly jet stream over Israel. During NRRs a similar wind vector anomaly pattern is observed east of Israel (Fig. 4a), while over Israel a very weak anomaly prevails.

During the rainy months (represented here by the month of March) there is a clear difference in the divergence field at $200 \mathrm{hPa}$ between these two rain categories. There is a divergence center (about $2-4 \times 10^{-6} / \mathrm{s}$ ) over, or few degrees east of Israel during RST rains (Fig. 5b). For NRRs, a divergence center is observed near $45^{\circ} \mathrm{E}$ (Fig. 5a). Apparently, the upper-level dynamics does not play a role in rain formation under NRR (in agreement with Kahana et al., 2002).

\subsection{Moisture field}

Moisture flux calculations were carried out for several atmospheric pressure levels (see also Zangvil and Isakson, 1995). In Fig. 6 vertical profiles of the moisture flux at the point $32^{\circ} \mathrm{N}, 35^{\circ} \mathrm{E}$ (center of Israel) associated with RST rains and NRRs are shown for comparison. The NRRs are associated with a maximum moisture flux at $900 \mathrm{hPa}$ (Fig. 6b), while (a)

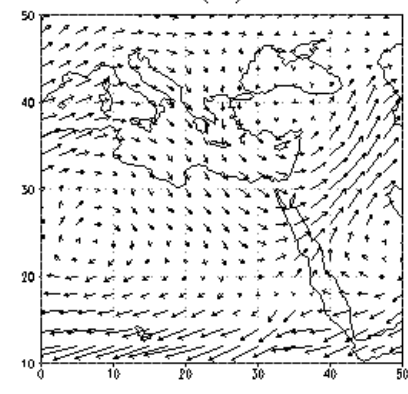

$\overrightarrow{90}$

(c)

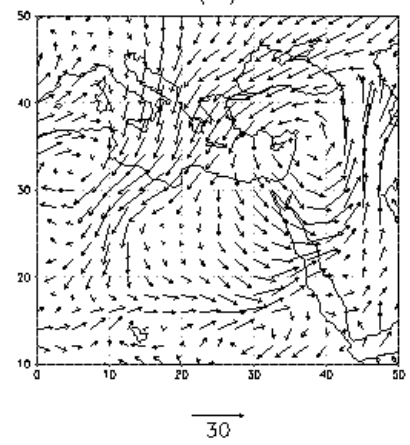

(b)

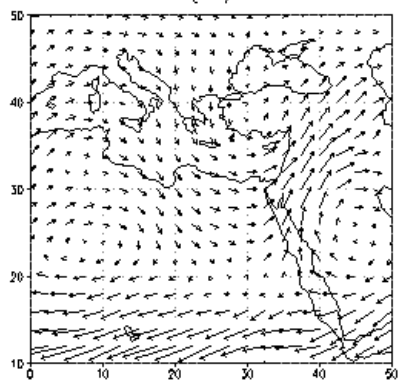

$\overrightarrow{90}$

(d)

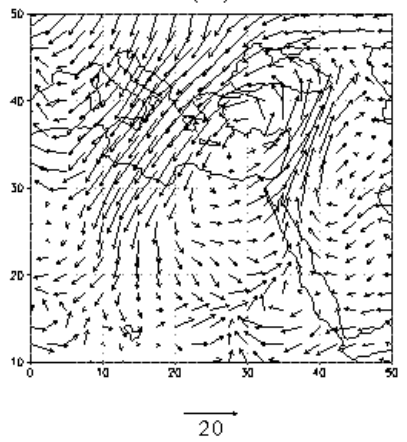

Fig. 7. Composite (1985-1995) of the moisture flux vector $\boldsymbol{q} \times \boldsymbol{V}$ ( $\boldsymbol{q}$ is the specific humidity and $\boldsymbol{V}$ is the horizontal wind vector) at $700 \mathrm{hPa}$ in October, for (a) non-RST rain; (b) RST rain; (c) nonRST rain, deviation from the (1985-1995) monthly mean; (d) RST rain, deviation from the (1985-1995) monthly mean. Arrows denote the value of the vector scale $[\mathrm{m} / \mathrm{s}]$.

RST rains are associated with maximum moisture flux at $700 \mathrm{hPa}$ and minimum at $900 \mathrm{hPa}$ (Fig. 6a). The NRRs profile implies a westerly Mediterranean moisture source (the $900 \mathrm{hPa}$ maximum flux may be explained by the wind speed increase with height). The weak, secondary maximum flux at $300 \mathrm{hPa}$ common to both the RST and non-RST rains, Fig. 6a can be explained by the presence of the Subtropical Jet Stream at that level.

The maximum moisture flux at $700 \mathrm{hPa}$ associated with RST rains (Fig. 6a) is most pronounced during the transition seasons, but exists also during the winter months. The secondary maximum at $950 \mathrm{hPa}$ can be explained by the northwesterly maritime flow near the surface associated with the RST (Fig. 3c).

Figures 7,8 show the moisture flux vector $(\boldsymbol{q} \times \boldsymbol{V})$ at 700 and $900 \mathrm{hPa}$, respectively, during RST rains and NRRs. During NRRs there is pronounce north-westerly moisture flux vector both at $700 \mathrm{hPa}$ (Figs. 7a, c) and at $900 \mathrm{hPa}$ (Figs. 8a, c), implying an immediate moisture transport from the Mediterranean, in agreement with Zangvil and Druian (1990) and Zangvil et al. (2003). 
(a)

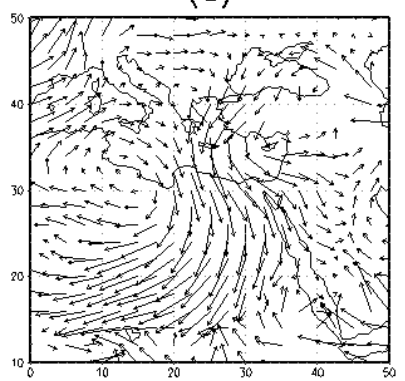

60

(c)

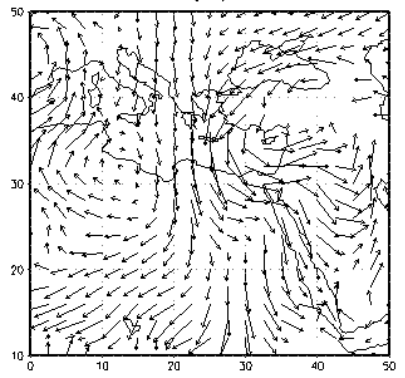

40 (b)

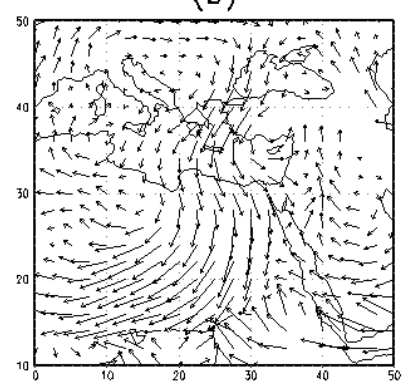

$\overrightarrow{60}$

(d)

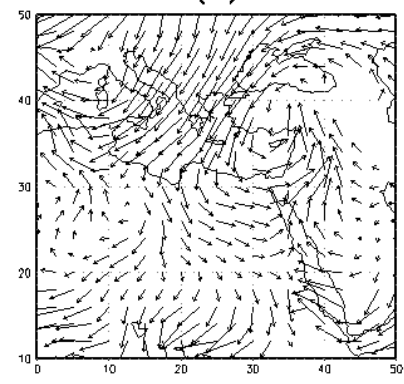

$\overrightarrow{30}$
Fig. 8. Same as Fig. 7, but for $900 \mathrm{hPa}$.

During RST rains there is northward moisture flux from the southern Red Sea along $40^{\circ} \mathrm{E}$ at $900 \mathrm{hPa}$, implying moisture transport from the Indian Ocean or the Arabian Sea (Fig. 8b). This flux is related to the prevailing near-surface flows at the eastern part of the RST (Fig. 3a). Figure 8d shows that these flows turn back over Turkey and arrive as north-westerly flows and moisture flux from the EM into Israel. At $700 \mathrm{hPa}$, the level of maximum moisture flux, (Fig. 6a) there is a pronounced south-westerly moisture flux from equatorial Africa to Israel and vicinity (Figs. 7b and d). In spring when the land-sea temperature differences are large and the sea breeze with its west to northwesterly maritime winds is active during the day, the moisture entering the country may play some role in the development of convective storms over the eastern parts of the country. Near the coast the relatively cool sea breeze air may have a stabilizing effect.

The difference in $700 \mathrm{hPa}$ moisture flux between RST rains and NRRs is well correlated with the upper trough structure and position differences between these two rainfall categories, as described in Sect. 3.1. The western position and the relatively deep southward penetration of the upper trough accompanying RST rains, causes south-westerly moisture flux transported by the flow ahead of the trough. During NRRs the upper trough axis is located over Israel, causing north-westerly moisture flux at the rear of the trough. (a)

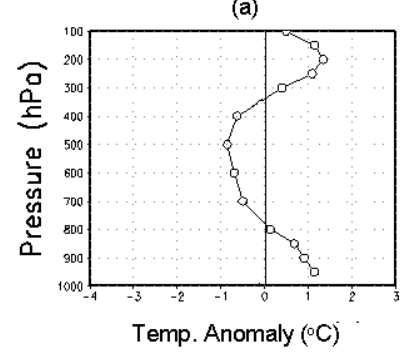

(b)

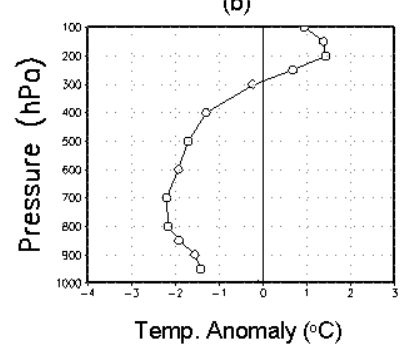

Fig. 9. Vertical profiles of temperature deviations from the time mean (1985-1995) at $32^{\circ} \mathrm{N}, 35^{\circ} \mathrm{E}$ in November, for (a) RST rain; (b) non-RST rain. Number of cases (map times) in composites for RST rain: 111, and for non-RST rain: 150.

\subsection{Vertical temperature profile}

Figure 9 shows the vertical temperature profile at $32^{\circ} \mathrm{N}$, $35^{\circ} \mathrm{E}$ associated with RST rains and NRRs. In order to emphasize the differences between these two categories, the temperature values are presented as the deviation from the long-term monthly mean.

In RST rains there are positive temperature anomalies near the surface, changing to negative above $800 \mathrm{hPa}$ (Fig. 9a). The positive temperature anomalies near the surface result from warm advection by the southeasterly flows associated with the RST. On the other hand, the upper trough that accompanies RST rains may explain the negative temperature anomalies in the $800-300 \mathrm{hPa}$ layer. The temperature anomalies in the $300-100 \mathrm{hPa}$ layer are most likely related to changes in tropopause height. In RST rains the positive anomalies above $300-200 \mathrm{hPa}$ are related to the cooling under this layer, which are also reducing the tropopause height. The 300-100 $\mathrm{hPa}$ layer is probably located at the lower part of the stratosphere in which the temperature normally increases with height.

In NRRs there is a negative temperature anomaly from the surface up to about, $300 \mathrm{hPa}$, where it changes to a positive anomaly (Fig. 9b), controlled by changes in tropopause height, as explained before. During NRRs the negative anomalies are larger by, up to $2.5^{\circ} \mathrm{C}$ (near the surface) compared to RST rains. This difference reflects the southwesterly flow aloft, accompanied by winds from the easterly quadrant near the surface associated with RST rains. These flows are warmer than the northwesterly upper flow associated with NRRs.

Figure 9 shows that the temperature lapse-rate between the surface and $500 \mathrm{hPa}$ is steeper during RST rains compared with the NRRs, enhancing unstable atmosphere conditions during RST rains. During NRRs there is strong cooling throughout the troposphere with a maximum cooling near $700 \mathrm{hPa}$, while during RST rains a steeper lapse-rate occurs, resulting from some cooling between 750 to $350 \mathrm{hPa}$ and pronounced heating near the surface. 


\section{Summary and conclusions}

This paper presents results of synoptic climatological comparative analysis between rain situations associated with RST, and those not connected with RST (non-RST rain, NRR). The RST situations were identified objectively by a new, simple algorithm applied to the NASA GEOS-1 reanalysis 6- hourly gridded data set $\left(2^{\circ}\right.$ Lat. $\times 2.5^{\circ}$ Lon $)$ for the period of March 1985-November 1995. The RST rain situations over Israel were defined on the basis of daily rainfall data in Israel in conjunction with the objectively defined RSTs.

Results show that near the surface NRRs are associated with a closed cyclone located over the Syrian coast-line or further east, over northern Syria, and with a negative sea level pressure anomaly center over northeastern Syria, near $37.5^{\circ} \mathrm{N}, 40^{\circ}$ E. The RST rains are associated with a sea level pressure trough extending northward over Israel and the eastern Mediterranean, the Red Sea Trough, and a negative sea level pressure anomaly near $30^{\circ} \mathrm{N}, 40^{\circ} \mathrm{E}$.

Although both types of rain situations are associated with $500 \mathrm{hPa}$ cold troughs there are pronounced differences in the structure and location of the troughs. The RST rain is accompanied by a mean, relatively narrow trough (about $20^{\circ}$ longitude in width), located $2.5^{\circ}$ longitude west of the Israeli coast-line (up to about 5-7.5 degrees during the transition season months) and characterized by a relatively deep southward penetration, to about $15^{\circ} \mathrm{N}$. On the other hand, NRR is accompanied by a wider upper trough (about $30^{\circ}$ width), located over the Israeli coast-line but with a shallower southward penetration, only to about $25^{\circ} \mathrm{N}$. As mentioned in Sect. 3.1 we should bear in mind that the apparent wider upper trough for the non-RST cases may reflect the variety of troughs and does not necessarily indicate that the individual troughs belonging to this class are wider.

We found a south-southwesterly wind vector anomaly at $200 \mathrm{hPa}$ over Israel during RST rains, especially in the fall and spring months, while during NRRs a similar wind vector anomaly pattern is observed east of Israel, and a very weak anomaly prevails over Israel. We also found a marked difference in the divergence field at $200 \mathrm{hPa}$ between these two rain categories: There is a divergence center (about $2-4 \times 10^{-6} / \mathrm{s}$ ) over, or few degrees east of Israel during RST rains. For NRRs, a divergence value of about 0 is observed over Israel with a divergence center located east of Israel, near $32^{\circ} \mathrm{N}$, $47^{\circ} \mathrm{E}$.

The vertical profiles of moisture flux, $q \times v$, near the center of Israel show that NRRs are associated with a maximum moisture flux at $900 \mathrm{hPa}$, while RST rains are associated with maximum moisture flux at $700 \mathrm{hPa}$ (most pronounced during the transition seasons) and a minimum at $900 \mathrm{hPa}$. During NRRs there is a pronounced west to north-westerly moisture flux vector both at $700 \mathrm{hPa}$ and at $900 \mathrm{hPa}$, implying an immediate moisture source from the Mediterranean. During RST rain situations two moisture sources may be oper- ating: 1. Equatorial Africa and/or the Indian Ocean by the southwesterly $700 \mathrm{hPa}$ mid-tropospheric flow. 2. The EM by the west-northwesterly flow near the surface. More research in needed to assess the exact partition of the water vapor in the rainfall, between these two moisture sources. The westerly position and the relatively deep southward penetration of the upper trough accompanying RST rains, may explain the moisture transported by the southwesterly flow ahead of the trough. On the other hand, prior to NNRs the upper trough does not penetrate southward enough to draw tropical moisture ahead of the upper trough. During NRRs the upper trough axis is located over Israel, causing Mediterranean westerly to north-westerly moisture flux at the rear of the trough.

In RST rains there are positive temperature anomalies near the surface, changing to negative near $900-800 \mathrm{hPa}$, while in NRRs there is a negative temperature anomaly from the surface up to about, $300 \mathrm{hPa}$. During NRRs the negative anomalies were found to be larger by up to $2.5^{\circ} \mathrm{C}$ compared to RST rains. This difference reflects the southwesterly flow aloft associated with RST rains, which is warmer than the west to northwesterly upper flow associated with NRRs. Still, a steeper temperature lapse-rate was found during RST rain compared with NRR enhancing unstable atmospheric conditions during these rains.

Finally, the reason why an RST develops ahead of shallow upper troughs is that these troughs are displaced to the south and thus instead of generating the usual Cyprus low they generate a low a few hundred $\mathrm{km}$ to the south of Cyprus. This low pressure system may not assume a circular shape of a closed low since it tends to merge with the semi-permanent quasi-stationary RST (see also, Karas and Zangvil, 1999) having an orographic and or thermal origin. Because of its southerly displacement, this synoptic system is able to draw moisture from tropical origins and thus the warm sector of the surface low (or RST) may become moister than the usual, non RST rain bearing trough. As a result, warm sector or warm frontal-like showers and thunderstorm activity may develop. This is the main difference between the RST rain and the non RST or usual winter rain in Israel.

Acknowledgements. The reanalysis data was made available to us by ISA-MEIDA, Tel Aviv University. Daily rain data from 10 stations over Israel were obtained from the Israel Meteorological Service. Thanks are due to anonymous reviewers for helpful comments and to D. Klepach for his assistance in programming.

Edited by: P. Alpert, H. Saaroni, and E. Heifetz

Reviewed by: two anonymous referees 


\section{References}

Air Ministry, Meteorological Office: Weather in the Mediterranean, Vol. I, London, HMSO, 362 pp., 1962.

Alpert, P. and Shay-El, Y.: The moisture source for the winter cyclones in the Eastern Mediterranean, Israel Meteorological Research Papers, 5, 20-27, 1994.

DaSilva, A. and Alpert, P.: Documentation of the multi-year GEOS1 assimilation data subset for Northern Africa, the Mediterranean and the Middle East. NASA, Goddard Space Flight Center, DAO Office Note 96-05, 24 pp., Feb. 1996.

Dayan, U. and Sharon, D.: Meteorological parameters for discrimination between widespread and spotty storms in the Negev, Israel J. Earth Sci., 29, 253-256, 1980.

Doty, B. E.: Grid Analysis and Display System (GrADS), Center for Ocean-Land-Atmosphere Interaction, Institute for Global Environment and Society, Calverton, MD, 1988.

Fengjun, J.: The connection between water vapor budget components and rainfall in the Eastern Mediterranean, M.S. Thesis, Blaustein International School for Desert Studies, Ben Gurion University, 63 pp., 2005.

Goldreich, Y.: The Climate of Israel: Observation, Research and Applications, Kluwer Academic/Plenum Publishers, New York, 298 pp., 2003.

Itzigsohn, D.: Dynamical and climatological analysis of interactions between the tropics and mid-latitudes in the Red Sea area, MSc Thesis, Department of Geophysics and Planetary Sciences, Tel Aviv University (in Hebrew), 137 pp., 1995.

Kahana, R., Ziv, B., Enzel, Y., and Dayan, U.: Synoptic climatology of major floods in the Negev Desert, Israel, Int. J. Climatol., 22, 867-882, 2002.

Karas, S. and Zangvil, A.:. A preliminary analysis of disturbance tracks over the Mediterranean Basin, Theor. Appl. Climatol., 64, 239-248, 1999.

Kidron, G. J. and Pick, K.: The limited role of localized convective storms in runoff production in the western Negev Desert, J. Hydrol., 229, 281-289, 2000.

Krichak, S. O, Alpert, P., and Krishnamurti, T. N.: Interaction of topography and tropospheric flow - a possible generator for the Red Sea Trough?, Meteorol. Atmos. Phys., 63(3-4), 149-158, 1997a.

Krichak, S. O., Alpert, P., and Krishnamurti, T. N.: Red Sea Trough/cyclone development - numerical investigation, Meteorol. Atmos. Phys., 63(3-4), 159-169, 1997b.
Leguy, C., Rindsberger, M., Zangvil, A., Issar, A., and Gat, J. R.: The relation between the oxygen-18 and deuterium contents of rainwater in the Negev desert and air mass trajectories, Chem. Geol. (Isotope Geoscience Sec.), 1, 205-218, 1983.

Malka, S.: Analysis of the water vapor field and synoptic characteristics in relation to temporal and regional variation of precipitation in Israel, M.S. Thesis, Blaustein International School for Desert Studies, Ben Gurion University, 99 pp., 2006 (in Hebrew).

Saaroni, H., Ziv, B., Bitan, A., and Alpert, P.: Easterly wind storms over Israel, Theor. Appl. Climatol., 59, 61-77, 1998.

Sasson, A.: Connection between synoptic characteristics and atmospheric moisture field and major rain storms over Israel, Masters Thesis, Dept of Geography and Institute for Desert Research, Ben Gurion University, 115 pp., 1990 (in Hebrew).

Sasson, A. and Zangvil, A.: Preliminary report on the connection between the atmospheric moisture field measured by the METEOSAT-2 satellite and precipitation in Israel, Israel Meteorological Research Papers, 5, 79-82, 1994.

Tsvieli, Y. and Zangvil, A.: Synoptic climatological analysis of "wet" and "dry" Red Sea Troughs over Israel, Int. J. Climatol., 25, 1997-2015, 2005.

Tsvieli, Y.: Synoptic climatological analysis of "wet" and "dry" Red Sea Troughs over Israelm Ph.D thesis, Department of Geography and Environmental Development, Ben-Gurion University of the Negev, Israel, 98 pp., 2006 (in Hebrew).

Yakir, D., Lev-Yadun, S, and Zangvil, A.: El Nino and tree growth near Jerusalem over the last 20 yearsm Global Change Biol., 2, 97-101, 1996.

Zangvil, A. and Shemer, D.: The climate of the Negev, in: Atlas of the Negev, edited by: Stern, E., Gradus, Y., Meir, A., Krakover, S., and Tsoar, H., Department of Geography, and the Blaustein Institute for Desert Research, Ben-Gurion University of the Negev, Beer-Sheva, 1986 (in Hebrew).

Zangvil, A. and Druian, P.: Upper air trough axis orientation and the spatial distribution of rainfall over Israel, Int. J. Climatol., 10, 57-62, 1990.

Zangvil, A. and Isakson, A.: Structure of the water vapor field associated with an early spring rainstorm over the eastern Mediterranean, Israel J. Earth Sci., 44, 159-168, 1995.

Zangvil, A., Karas, S., and Sasson, A.: Connection between Eastern Mediterranean seasonal mean $500 \mathrm{hPa}$ height and sea-level pressure patterns and the spatial rainfall distribution over Israel, Int. J. Climatol., 23, 1567-1576, 2003.

Ziv, B.: The weather in Israel, in: Introduction to Meteorology, edited by: Ziv, B., and Yair, Y., The Open University Press, Tel Aviv, Israel, Unit 5, 8-59, 1994 (in Hebrew). 